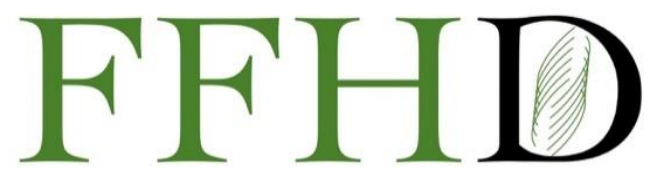

Functional Foods in Health and Disease

\title{
Production and nutritional composition of juice powder from oyster mushroom Pleurotus ostreatus (Jacq.) Kummer
}

\author{
Lauretta Nwanneka Ofodile ${ }^{1}$, Nwachukwu Viola A. Nicholas-Okpara², Emmanuel Ani ${ }^{3}$, \\ Emmanual Mmaduabuchi Ikegwu ${ }^{4}$, Anjorin Saanu ${ }^{1}$, Peace Chidinma Ezenwa ${ }^{5}$ and Rafiat \\ Titlope Osorinde ${ }^{5}$
}

${ }^{1}$ College Central Research Laboratory, Yaba College of Technology, P.M.B 2011, Yaba Lagos; ${ }^{2}$ Food Technology Department, Federal Institute of Industrial Research, Oshodi, Lagos, Nigeria; ${ }^{3}$ Environmental Biology Unit, Yaba College of Technology, Yaba, Lagos; ${ }^{4}$ Department of Statistics, Yaba College of Technology, Yaba, Lagos; ${ }^{5}$ Department of Biological Science, Microbiology Section, Yaba College of Technology, Yaba Lagos, Nigeria

Corresponding Author: Dr. Ofodile, Lauretta Nwanneka, College Central Research Laboratory, Yaba College of Technology, P.M.B 2011, Yaba, Lagos. Nigeria.

Submission Date: September 23 ${ }^{\text {rd }}, 2020$; Acceptance Date: November 16 ${ }^{\text {th }}, 2020$; Publication Date: November $27^{\text {th }}, 2020$

Please cite this article as: Ofodile L.N., Nicholas-Okpara N.V.A., Ani E., Ikeqwu E.M., Saanu A., Ezenwa P.C., Osorine R.T. Production and nutritional composition of juice powder from oyster mushroom Pleurotus ostreatus (Jacq.) Kummer. Functional Foods in Health and Disease 2020. 10(11): 482-492. DOI: https://www.doi.org/10.31989/ffhd.v10i11.751

\section{ABSTRACT}

Background: Mushrooms have been used as functional foods, nutraceuticals and medicines for decades in Asian countries. Because of their vital roles in human health, nutrition, and well-being, they are described as treasures in the wild and have served as food supplements. In regard to their nutritional composition, they are relatively low in total fat, vitamins, minerals, and fiber, but rich in high quality proteins and polyunsaturated fatty acids.

Objective: To determine the nutritional value and proximate analysis of the oyster mushroom Pleurotus ostreatus, formulate mushroom juice powder, and determine its nutritional composition of the powder

Methods: Optimization of the processing condition of the mushroom Pleurotus ostreatus (Jacq.) Kummer

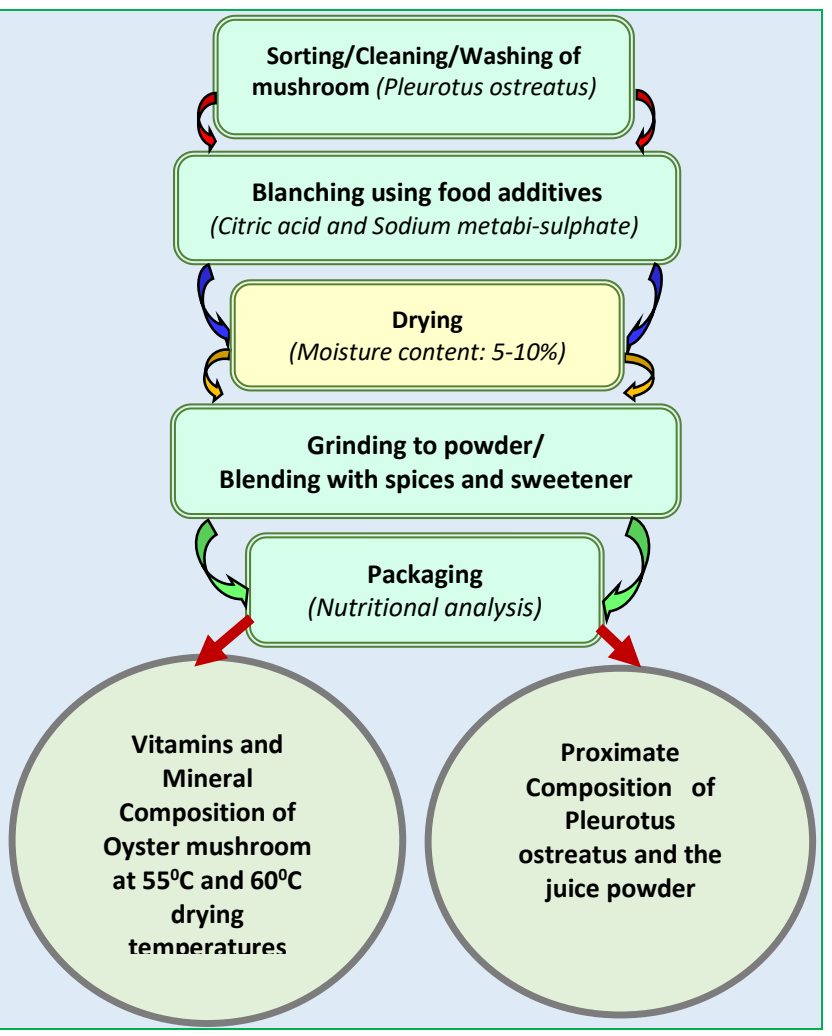


was first conducted using four different drying temperatures; $55^{\circ} \mathrm{C}, 60^{\circ} \mathrm{C}, 65^{\circ} \mathrm{C}$ and $70^{\circ} \mathrm{C}$ hourly for 3 hours to determine the best drying temperature. The temperatures at which the juice retained $5-10 \%$ moisture were selected for preparation of condensate and analysis because they had the best nutrient composition. Stevia (plant sugar) was used as a sweetener and ginger as the flavor for the formulation of the juice powder. A nutritional composition analysis of the juice powder was also carried out.

Results: The nutritional composition of dried $P$. ostreatus at the chosen drying temperature $\left(55^{\circ} \mathrm{C}\right)$ were $(8.71$, $9.45,7.07,9.38,51.81$ and $13.3 \mathrm{mg} / \mathrm{g}$ ) for iron, manganese, copper, zinc, magnesium and calcium respectively. Nutritional values Fe, Mn, Cu, Zn, Mg and Ca for the juice powder were 8.96 mg/g, 12.1mg/g, $7.94 \mathrm{mg} / \mathrm{g}, 11.88$ $\mathrm{mg} / \mathrm{g}, 59.0 \mathrm{mg} / \mathrm{g}$ and $42.0 \mathrm{mg} / \mathrm{g}$ respectively. The vitamin content of initial P. ostreatus raw material were Vitamin B1 (4.99) and B6 (0.74) while for the juice powder B1, B6 and C were $0.78 \mathrm{mg} / \mathrm{g}, 0.035 \mathrm{mg} / \mathrm{g}$ and $0.21 \mathrm{mg} / \mathrm{g}$ respectively. Proximate analysis showed that the mushroom contained moisture (11.20 $\pm 0.47 \%)$, fat $(0.55 \pm 0.07 \%)$, protein $(39.75 \pm 0.53 \%)$, fiber $(3.30 \pm 1.04 \%)$, ash $(8.65 \pm 0.52 \%)$ and carbohydrate $(36.54 \pm 0.50 \%)$ while juice powder contained moisture $(5.0 \%)$, fat $(1.0 \%)$, protein(27.13\%), fiber $(16.00 \pm 2.52 \%)$, ash $(2.83 \pm 0.12 \%)$ and carbohydrate(48.04 $\pm 2.58 \%)$.

Conclusion: This work demonstrated that the nutrient composition of the mushroom improved when formulated into juice powder. The quantity of $\mathrm{Zn}$ and Ca significantly increased in the juice powder at $p<0.05$ and reached the recommended daily dietary allowances and adequate intakes.

Keywords: Pleurotus ostreatus, Juice powder, Nutritional value, formulation

CFFC 2020. This is an Open Access article distributed under the terms of the Creative Commons Attribution 4.0 License (http://creativecommons.org/licenses/by/4.0)

\section{INTRODUCTION}

Mushrooms are fleshy fungi forming an umbrella-like fruiting body. They do not have green chlorophyll and therefore do not manufacture their food. Mushrooms have microscopic spores, which is a means of reproduction. They are widely distributed in temperate and tropical regions, and it actually take days or weeks for one to grow, develop and mature $[1,2]$. Mushrooms have been used as diets, nutraceuticals, and drugs for years in Asian countries $[3,4]$. Mushrooms are known as one of the most vital diet enhancements for their important roles in human health, nutrition, and various diseases. They consist of many bioactive compounds, including primary metabolites that could avert oxidative stress
[5] as well as secondary metabolites such as polysaccharides (mainly $\beta$-D-glucans), heteroglycans, chitinous substances, peptidoglycans, proteoglycans, lectins, RNA components, lectins, lactones, alkaloids, terpenes, flavonoids, terpenoids, steroids, phenols, glycoproteins, nucleotides, fatty acids, vitamins, proteins, amino acids, antibiotics and minerals that have positive impacts on the human body and protect it from the diseases [4, 5]. These bioactive compounds are superb antioxidants and antiinflammatory agents beneficial to the central nervous system, heart, kidney, and liver [6]. Also, it has been proven that these bioactive compounds act as chemopreventive agents and prevent most serious 
diseases, including diabetes, obesity, CVD, and neurodegenerative diseases [7].

Nutritional analyses found that edible mushrooms contain vital nutrients and have good taste, flavor, and some physiological functions [8]. They are rich in high-quality proteins, polyunsaturated fatty acids (with a relatively low content of total fat), vitamins, minerals, and fiber. Mushrooms produce low energy which is good for weight loss, contain low glucose and high mannitol, which is good for diabetics, and has no cholesterol and low sodium, which is good for people suffering from hypertension [6, 8]. Furthermore, mushrooms have a high content of vitamin D and B-complex with a high content of minerals and a significant quantity of many trace elements, especially of selenium, which is a potent antioxidant [9].

In addition to their nutritive value, edible mushrooms have unique features in terms of color, palate, flavor, odor, and texture that make them more attractive for human ingestion. Several studies have recommended regular ingestion of certain mushrooms either as a regular food or as extracted compound (nutraceuticals). Some of these compounds (polysaccharides) are active in both preventing and treating various diseases [8]. The high content of natural sugars in $100 \%$ fruit juice may cause health complications similar to juice containing synthetic sugars, as the natural sugars are broken down and absorbed as glucose and fructose, which is the same as juice containing artificial sugars [10]. Fresh mushrooms are highly perishable with short shelf life under ambient environment, temperature, and humidity, making their commercialization difficult. Among the various techniques employed for the conservation of mushrooms, drying seems to be an effective approach to extend shelf life and ensure distribution [11-12]

There seems to be no report of powdered juice formulated with P. ostreatus grown in Nigeria and its nutritional value. This paper reports the process of production of juice powder from oyster mushroom and its nutritional composition.

\section{MATERIALS AND METHODS:}

Sample collection: The oyster mushroom was collected from the Mushroom Research and Training Laboratory at Yaba College of Technology, Lagos. The plants used as a sweetener (Stevia rebaudiana) and as flavor (Zingiber officinale) were bought from a local (Yaba) market.

Optimization of processing condition: Four different samples of the mushroom, each weighing $150 \mathrm{~g}$ were dried using a dehydrator (Daewoo, Yuyao Ouyou Electric Appliance Technologies, Co. Ltd) at temperatures $\left(55^{\circ} \mathrm{C}, 60^{\circ} \mathrm{C}, 65^{\circ} \mathrm{C}\right.$ and $\left.70^{\circ} \mathrm{C}\right)$ for 3 hours. The samples for each temperature were divided into three, and $50 \mathrm{~g}$ of each sample was dried using a dehydrator. Initial moisture content and relative humidity at intervals of $1 \mathrm{hr}$ were determined for 3 hours. Samples with 5-10\% moisture content were analyzed based on their minerals and vitamin composition to determine the best drying temperature to use for further work.

\section{Preparation of juice powder using oyster mushroom:} Mushroom (200g) was sorted, cleaned and washed after which it was blanched using citric acid and sodium metabisulphite, drained and dried at optimized temperature and time using a dehydrator. The dried mushroom was blended to powder, and 
then mixed with $30 \mathrm{~g}$ of stevia (plant sugar) and $10 \mathrm{~g}$ ginger powder (Fresh ginger was dried, ground and sieved to remove fiber). Proximate analysis was done on the mushroom and the juice powder from the mushroom.

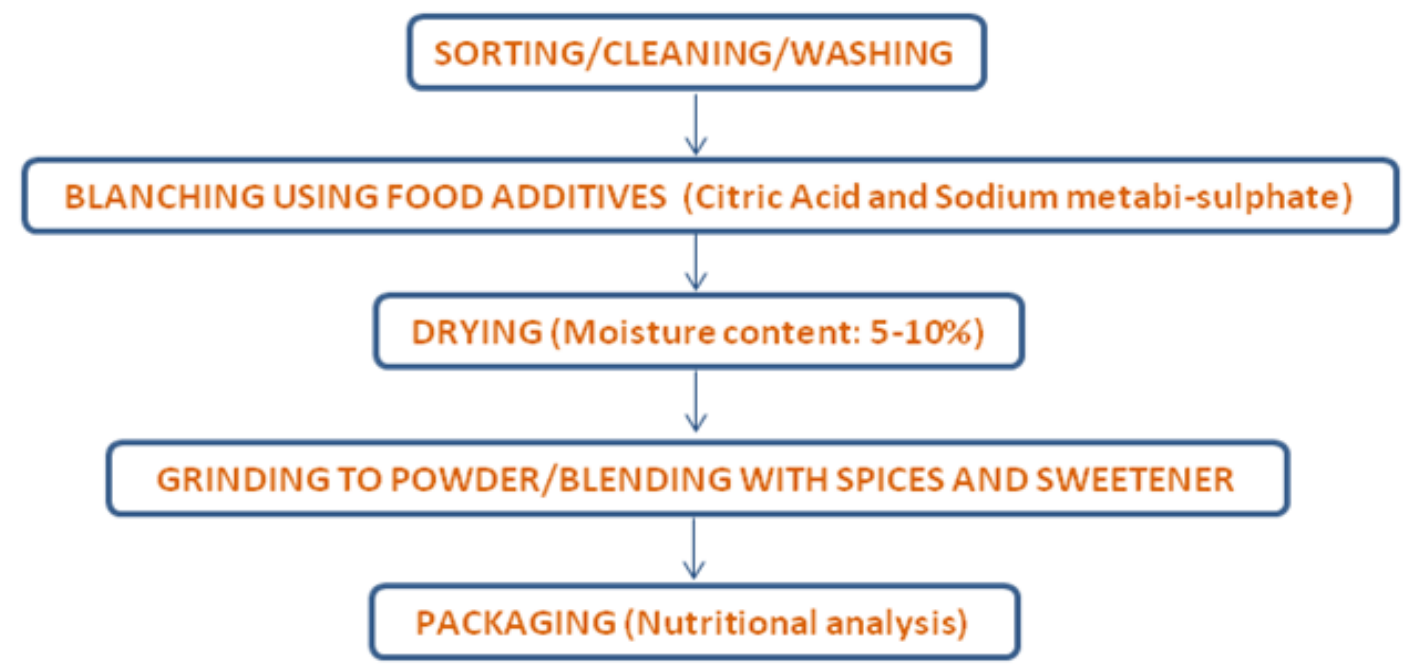

Figure 1. Production flow chart for the preparation of juice powder using Pleurotus ostreatus

Determination of Crude Fat: Crude fat was determined by the solvent extraction method [13]. Juice powder $(10 \mathrm{~g})$ and dried powdered mushroom $(10 \mathrm{~g})$ were weighed and transferred into 3 different beakers and $50 \mathrm{ml}$ petroleum ether was added to each of the beakers and left for 1 hour in the fume cupboard and swirled occassionally. The petroleum ether was then decanted into an empty petri dish and allowed to evaporate. This process was repeated for the other two samples. The Petri dishes were weighed after evaporation and the weight of fat was calculated. The percentage of crude fat content was also calculated.

Weight of fat $=$ Weight of petri dish after evaporation the weight of empty petri dish

Determination of Crude Fiber: Total amount of fiber was determined using the AOAC method [14]. The defatted samples were weighed and put into a flat bottom flask. $\mathrm{H}_{2} \mathrm{SO} 4(50 \mathrm{~mL})$ was added, and the mixture was boiled for 30 minutes after which it was sieved, washed with distilled water, and put back into the flat bottom flask. $\mathrm{KOH}(50 \mathrm{~mL})$ was added to the residue, and the mixture was boiled for another 30 minutes, sieved and washed with distilled water. The residue was put into a beaker containing $10 \mathrm{ml}$ of acetone, and left for 20 minutes and then filtered. The samples were dried in the oven for 30 minutes at $130^{\circ} \mathrm{C}$.

Determination of Total Ash: The total amount of Fiber was determined by using AOAC method [14]. Residues from the crude fiber were weighed into porcelain crucibles which were previously ignited and weighed. The crucible was placed in a muffle furnace, which was maintained at 55 으 for 6 hours. It was then 
cooled in a desiccator until ash is obtained and weighed, and the ash content was calculated afterwards [14].

Determination of Crude Protein: Crude protein was determined using the modified Lowry method [15]. Defatted residues $(1 \mathrm{~g})$ each were soaked with $5 \mathrm{ml}$ of phosphate buffer in sample bottles and then put in the freezer for $1 \mathrm{hr} .1 \mathrm{ml}$ of each filtrate was put in 2 different test tubes and $1 \mathrm{ml}$ of buffer was tested as a blank. $3 \mathrm{ml}$ of reagent 1 was added to each of the test tubes and incubated at room temperature for 10 minutes after which $0.1 \mathrm{ml}$ of reagent 2 was added to each test tube and incubated at room temperature for 30 minutes. Absorbance was taken at 750nm wavelength.

Reagent 1: 48ml of Lowry's solution $\mathrm{Na} 2 \mathrm{CO} 3+1 \mathrm{ml}$

$$
\text { of } \mathrm{NaK}+1 \mathrm{ml} \text { of }
$$

Reagent 2: $1 \mathrm{ml}$ of Folinsocateur $+4 \mathrm{ml}$ of water

Determination of Total Carbohydrate: The total carbohydrate was determined by the difference method [16]. It was calculated with the following equation:

Crude Carbohydrate $(\%)=[100-(\%$ Total moisture + $\%$ Crude protein $+\%$ Crude fat $+\%$ Crude fiber $+\%$ Total ash)]

Vitamin C Content Determination: The modified method of [17] was used in the determination of ascorbic acid content. Juice powder (1g) and dried powdered mushroom (1g) were each dissolved in $25 \mathrm{ml}$ of $0.025 \mathrm{M}$ of phosphate buffer $\mathrm{pH} 3$ and kept in the freezer for 30 minutes, after which it was centrifuged at $4000 \mathrm{rpm}$ for 10 minutes. The filtrate was decanted into a sample bottle and then filtered with a micro-filter into another plastic bottle for HPLC analysis. The working condition of HPLC was as follows; HPLC detector: Agilent VWD detector: 254um, column: Zorbax Eclipse XDB C18 4.6×100mm, 3.5um, Mobile phase; CAN phosphate buffer $\mathrm{pH}$ $3(10: 90) \%$, Flow rate: $0.8 \mathrm{ml} / \mathrm{min}$, Temperature: Ambient.

Mineral Content Determination: Using the modified method based on APHA 3030A, 2017, mineral content was determined using the acid digestion method. Sample (1g) each was weighed accurately into a conical flask using Sartorius analytical balance and 10 $\mathrm{ml}$ of $\mathrm{HNO}_{3}$ (Nitric acid) were added in a fume cupboard. The mixture was heated on a hot plate, giving off brown fumes, and left to heat until all the brown fumes were given off. The conical flask was removed from the hot plate and allowed to cool. Distilled water $(20 \mathrm{~mL})$ was added to the content of the conical flask and then returned to the hot plate and allowed to boil to bring the metal into solution. The solution was allowed to cool and filtered into a $100 \mathrm{ml}$ volumetric flask using Whatman 42 filter paper. Distilled water was used to mark up to $100 \mathrm{ml}$ and then decanted into $100 \mathrm{ml}$ sample plastic for instrumental analysis. The minerals were evaluated through atomic absorption spectrophotometry [18] using atomic absorption spectrophotometer (AAS) 200 series (Agilent Technologies) Wald brown Analytical Div. B4, Germany.

Statistics and Analysis: Data collected from all experiments are expressed as mean \pm standard using IBM SPSS statistical package. Deviation (SD) at a $5 \%$ level of significance. 


\section{RESULTS AND DISCUSSION:}

Figure 2 shows the final weight and relative humidity of oyster mushroom at different drying temperatures conditions.

The result presented in Figure 2 shows the final weight and relative humidity of mushroom at different times and temperatures. Oyster mushroom dried $(50 \mathrm{~g})$ at $55^{\circ} \mathrm{C}, 60^{\circ} \mathrm{C}, 65^{\circ} \mathrm{C}$ and $70^{\circ} \mathrm{C}$ for 3 hrs had final weights of $8.5 \mathrm{~g}, 7.8 \mathrm{~g}, 8.8 \mathrm{~g}$ and $7.0 \mathrm{~g}$, respectively. The relative humidity for $55^{\circ} \mathrm{C}$ was $54 \%$, relative humidity at $60^{\circ} \mathrm{C}(69 \%), 65^{\circ} \mathrm{C}(53 \%)$ and $70^{\circ} \mathrm{C}(60 \%)$. This result showed that relative humidity varied at each drying time and temperature, there was no consecutive increase or decrease in relative humidity.
Comparing the final weight and relative humidity of $P$. ostreatus, the results presented in Figure 2 shows that the final weights were non-significantly different at different temperatures. Likewise, relative humidity showed no significant difference. Theweight of the mushroom reduced exponentially with temperature increase, so drying temperature had a significant effect on the moisture removal from the mushroom which was similar to the report of [19]. The relative humidity was reduced with an increase in temperature but not consistent with time [20]. Kulshrehlha et al., [21] also reported that the drying rate increased with an increase in temperature.

120.00

100.00

80.00

60.00

40.00

20.00

0.00

$-20.00$

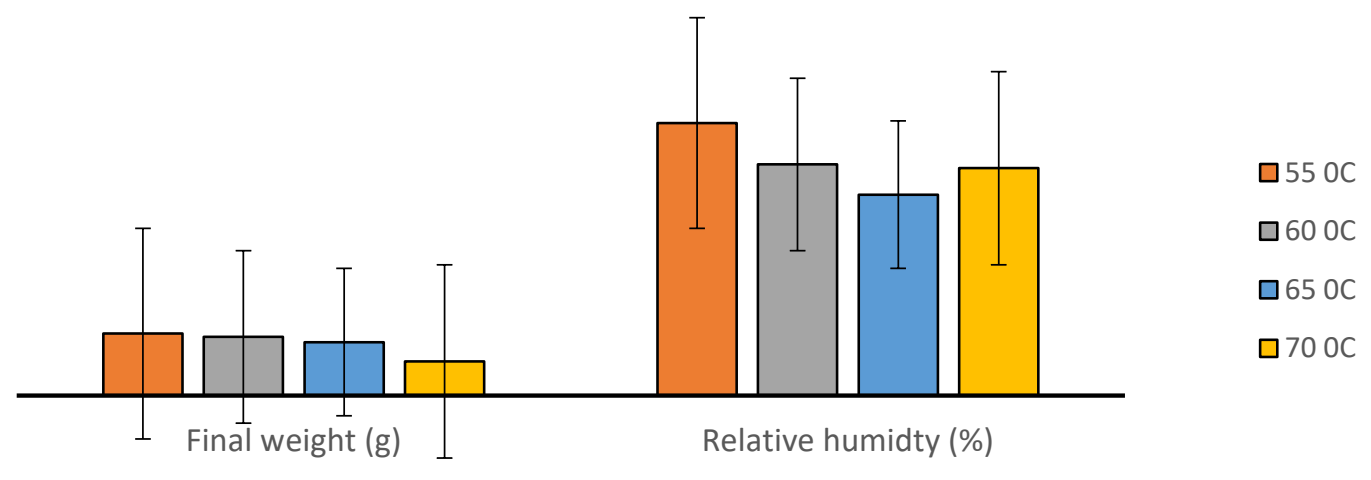

$-40.00$

Figure 2. Final weight and relative humidity of oyster mushroom at different drying temperatures (Mean \pm SD)

Table 1 shows the mean pattern of the oyster mushroom dried at different temperatures conditions.

Moisture Content: The result presented in Table 1 shows the moisture content at different times for the different drying temperatures. At 1 hour, oyster mushroom dried at $55^{\circ} \mathrm{C}, 60^{\circ} \mathrm{C} 65^{\circ} \mathrm{C} 70^{\circ} \mathrm{C}$ with moisture contents of $65 \%, 55 \%, 55 \%$ and $35 \%$, respectively. For 2 hours drying for the different temperatures, moisture contents were $28 \%, 13 \%$, $10 \%$ and $13 \%$, respectively. At 3hours, $65^{\circ} \mathrm{C}$ and $70^{\circ} \mathrm{C}$ had no moisture while $55^{\circ} \mathrm{C}$ and $60^{\circ} \mathrm{C}$ had $5 \%$ moisture. The rate of moisture reduction increased as 
temperature increased from $55^{\circ} \mathrm{C}$ to $70^{\circ} \mathrm{C}$ which aligned with [20]. Water content affects food quality, it provides a medium to support microbial growth. Generally speaking, the more water that is present, the greater the opportunity for microbes to grow [22], as regards this, $65^{\circ} \mathrm{C}$ was eliminated due to the high moisture content of $10 \%$ which would decrease the shelf life of the mushroom. Drying air temperature of $50^{\circ} \mathrm{C}$ is better as it gives dried products with higher rehydration ratio, lower shrinkage and better color [21].

The moisture content of the mushroom per dry weight non-significantly decreased with increased temperature but constant at $60^{\circ} \mathrm{C}$ and $65^{\circ} \mathrm{C}$ although the initial moisture contents for the temperature were not the same. It was evident that higher temperatures increased the drying rate for the mushrooms [19].

Table 1: Mean Moisture pattern of oyster mushroom at the different drying temperature and time

\begin{tabular}{c|cccc}
\hline \multicolumn{5}{c}{ MOISTURE PATTERN (\%) } \\
\hline TIME/TEMP & OHR & $1 \mathrm{HR}$ & $2 \mathrm{HRS}$ & $3 \mathrm{HRS}$ \\
& & & & \\
$55^{\circ} \mathrm{C}$ & 70 & $65 \pm 0.0$ & $28 \pm 10.6$ & $5 \pm 0.0$ \\
$60^{\circ} \mathrm{C}$ & 60 & $55 \pm 0.0$ & $13 \pm 3.6$ & $5 \pm 0.0$ \\
$65^{\circ} \mathrm{C}$ & 70 & $55 \pm 0.0$ & $10 \pm 0.0$ & $0 \pm 0.0$ \\
$70^{\circ} \mathrm{C}$ & 75 & $35 \pm 0.0$ & $13 \pm 3.5$ & $0 \pm 0.0$ \\
\hline
\end{tabular}

Values reported are mean \pm standard deviation $n=2$

Figure 3 shows the vitamins and Mineral Composition of Oyster Mushroom Pleurotus ostreatus.

The result presented in Figure 3 shows the vitamins and mineral composition of oyster mushroom dried at $55^{\circ} \mathrm{C}$ and $60^{\circ} \mathrm{C}$ for 3 hours. Magnesium had the highest value of $55.81 \mathrm{mg} / \mathrm{g}$ dry weight while vitamin $B 6$ had the least value of 0.79 $\mathrm{mg} / \mathrm{g} / \mathrm{dry}$ wt. Mineral contents were higher in the juice powder than in the dried mushroom at $\mathrm{mg} / \mathrm{g}$ dry weight. Magnesium had the highest content in both the dried mushroom and juice powder (51.81 and $59.0 \mathrm{mg} / \mathrm{g}$ dry wt.) followed by calcium (13.30 and $42.0 \mathrm{mg} / \mathrm{g}$ dry wt.), respectively. This result is in line with Mallikarjuna et. al., [23]. Four different species of mushroom were reported as good sources of magnesium at $\mathrm{mg} / 100 \mathrm{~g}$ dry weight [23]. Juice powder had a higher content of zinc than the dried mushroom (11.88 and $9.38 \mathrm{mg} / \mathrm{g}$ dry wt.), respectively. Good content of zinc was also reported for Pleurotus djamor and Lentinus edodes with 9.21 and 9.44 $\mathrm{mg} / 100 \mathrm{~g}$ dry wt. [23]. Mushrooms are known as good accumulators of zinc, which is very vital to the human body [24] for the strong immune system, wound healing, and sense of smell.

The values of $\mathrm{Cu}, \mathrm{Zn}, \mathrm{Mg}$ and $\mathrm{Ca}$ were higher in the mushroom dried at $60^{\circ} \mathrm{C}$ but $\mathrm{Fe}, \mathrm{Mn}$, vitamin $\mathrm{B} 1$ and B6 were non-significantly higher at a drying temperature of $55^{\circ} \mathrm{C}$, possibly because higher temperature affects the mineral content of the mushroom. 


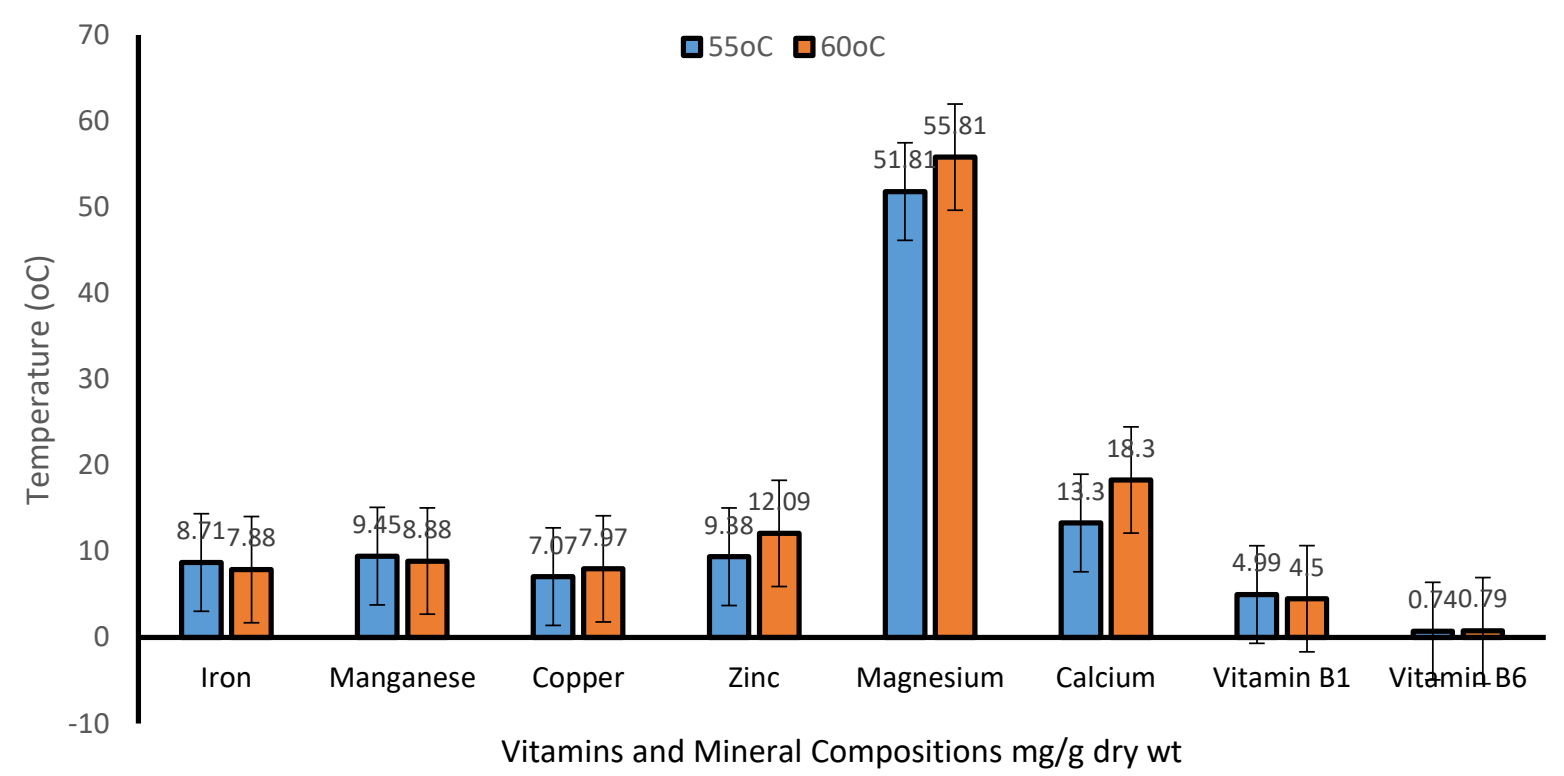

Figure 3: Vitamins and mineral composition of oyster mushroom at $55^{\circ} \mathrm{C}$ and $60^{\circ} \mathrm{C}$ drying temperatures

The result represented in Table 2 shows the vitamin and mineral composition of the juice powder, the recommended daily intake of the minerals and vitamins, and $\%$ daily value for juice powder.

The dry weight of iron was $8.96 \mathrm{mg} / \mathrm{g}$. which was 29.9 -

$32 \%$ of the recommended daily intake of iron. $\mathrm{Mn}, \mathrm{Cu}$,

$\mathrm{Zn}, \mathrm{Mg}$ and $\mathrm{Ca}$ contents in the juice powder were $12.1 \%, 7.94 \%, 11.88 \% 59.0 \%, 42.0 \%$ recommended daily intake of the minerals for adults [25]. The value of vitamin B1 was $4.99 \mathrm{mg} / \mathrm{g}$ for the mushroom dried at $55^{\circ} \mathrm{C}$ and $4.50 \mathrm{mg} / \mathrm{g}$ at $60^{\circ} \mathrm{C}$ which is in line with the work done by Celen et al.[19] in that higher temperature increases the risk of losing vitamins in mushrooms (Fig. 2). Table 2 shows that some of the minerals ( $\mathrm{Mg}, \mathrm{Cu}$, and $\mathrm{Zn}$ ) in the juice reached the recommended daily dietary allowances and adequate intakes for adults [25].

Table 2: Vitamin and mineral composition of juice powder with a daily recommended value

\begin{tabular}{l|lll}
\hline $\begin{array}{l}\text { Nutrients } \\
(\mathbf{m g} / \mathbf{g})\end{array}$ & $\begin{array}{l}\text { Juice Powder } \\
\left(\mathbf{5 5}^{\circ} \mathbf{C}\right)\end{array}$ & $\begin{array}{l}\text { Recommended } \\
\text { Value } \mathbf{( m g} / \text { day })\end{array}$ & $\begin{array}{c}\text { Daily } \\
\text { \% Daily Value For Juice } \\
\text { Powder }\end{array}$ \\
\hline Iron & $8.96 \pm 1.12$ & $28-30$ & $29.9-32$ \\
Manganese & $12.10 \pm 1.01$ & 5.5 & 220 \\
Copper & $7.94 \pm 0.11$ & 2.2 & 360 \\
Zinc & $11.88 \pm 0.21$ & 15.5 & 76.6 \\
Magnesium & $59.00 \pm 1.40$ & 360 & 16.4 \\
Calcium & $42.00 \pm 1.00$ & 1000 & 4.2 \\
Vitamin B1 & $0.78 \pm 0.30$ & 1.4 & 55.8 \\
Vitamin B6 & $0.04 \pm 1.10$ & 1.9 & 1.8 \\
Vitamin C & $0.21 \pm 0.11$ & 85 & 0.25 \\
\hline
\end{tabular}


Further processing could have affected the vitamin content of the juice powder because the vitamin $\mathrm{B} 1$ and $\mathrm{B} 6$ content in the mushroom (4.99 and $0.74 \mathrm{mg} / \mathrm{g}$ dry wt.) were higher than in the juice powder $(0.781$ and $0-035 \mathrm{mg} / \mathrm{g}$ dry wt.). A similar report was given by Mbuge and Mutai [26], stating that nutrient losses come from different steps in the process of drying also that elevated temperature degrades vitamins.

The temperature of $60^{\circ} \mathrm{C}$ has been reported as suitable for drying edible mushrooms as it preserves most nutritional values $[26,27]$. The report is in line with the results of the present study which recorded $55^{\circ} \mathrm{C}$ and $60^{\circ} \mathrm{C}$ preserved most of the nutrients in the mushroom and the juice powder. $55^{\circ} \mathrm{C}$ was chosen for the formulation of the juice because a lower temperature with $5 \%$ moisture content was preferable. $\mathrm{Cu}$ and $\mathrm{Mn}$ reached the recommended daily intake [28] Recommended daily intake (RDI) was as reported by the Indian Council of Medical Research [28].

Figure 4 shows proximate composition of the oyster mushroom and Juice Powder.

The result presented in Figure 4 shows the proximate composition of the Pleurotus ostreatus and juice powder which showed that moisture, fat, protein, fiber, ash and carbohydrate contents were $5.0 \%, 1.0 \%, 27.13 \%, 16.0 \pm 2.5160 \%, 2.83 \pm 0.1155 \%$ and $48.04 \pm 2.5813 \%$,respectively, for the juice powder, and $11.2 \%, 0.55 \%, 39.75 \% .3 .3 \%, 8.65 \%$ and $36.54 \%$, respectively, for the dried mushroom. Lowfat content was also recorded in the dried mushroom and the juice product confirming that mushroom, and its value-added product is nutritious and healthy. Yuen et al. [27] also reported low-fat content in the mushroom Volvoriella volvacea. Although the fat content in the juice is non-significantly higher than in the mushroom $\mathrm{mg} / \mathrm{g}$ dry wt.

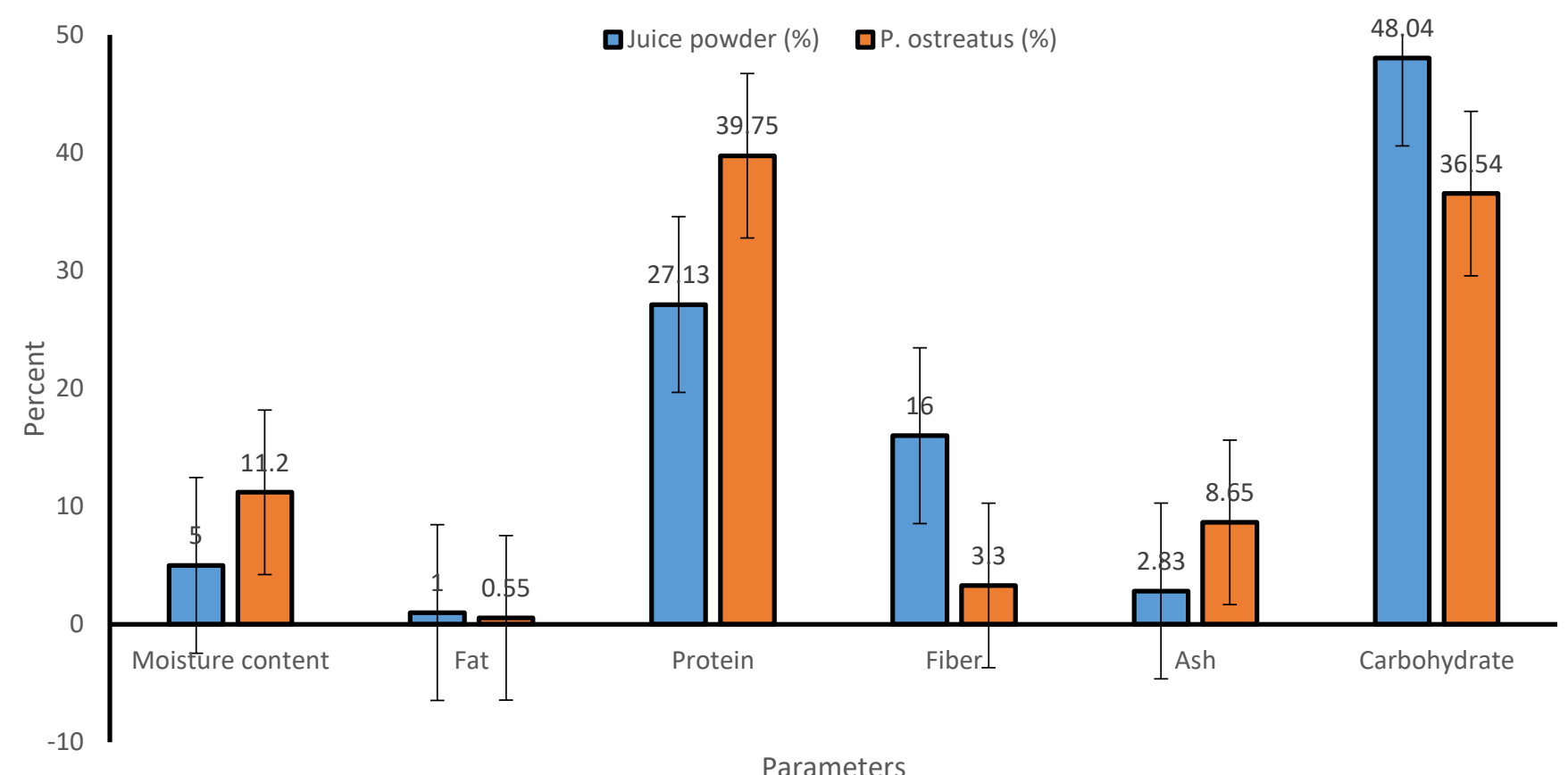

Figure 4: Proximate composition of Pleurotus ostreatus and juice powder made with Pleurotus ostreatus 
Protein content was non-significantly lower in the juice powder $(27.13 \%)$ while the fiber in the juice (16\%) was significantly $p<0.05$ higher compared to the dried mushroom (39.75\% and 3.3\%), respectively. Consequently, the mineral elements analyzed in this mushroom and its value-added juice powder was relatively comparable with reported literature values. The range of reported literature values $(\mathrm{mg} / 100 \mathrm{~g}$ dry weight basis) in mushroom for calcium, magnesium, iron, zinc, copper, manganese were 1.8-59.0[29], 60250[30], 1.46-83.5[31], 2.98-15 [32], 7.1-9.5 [31] and 1.81-10.3 [33] mg/100 g dry wt., respectively.

\section{CONCLUSION:}

Commercialization of edible fungi and its products has been a major challenge in Nigeria. Although $P$. oestratus has been known to contain several health and nutritional benefits, production and storage are still a major challenge in Nigeria.

The present results provide evidence that processing $P$. ostreatus to powdered juice does not diminish its food value but rather adds value to it. Therefore, the present mineral values increase the safe consumption of mushrooms as supplementary foods to the poor populations preponderantly dependent on cereal diet, as well as project the juice powder as a likely nutritional product.

Authors' contributions: Ofodile, L.N. designed, supervised the experiment and prepared the manuscript, Nicholas-Okpara, Viola A.N. designed the experiment; Saanu Anjorin conducted the heavy metal analysis, Ezenwa, P.C. and Osorinde, R.T. performed the laboratory study; Ikegwu Emmanual M. analyzed the data; Ani, E. prepared and revised the manuscript.
Competing interests: The authors declare that there are no competing interests and no funding was received for this research.

Acknowledgment: We are grateful to Mr. Oluwaseyi Famarkinwa for his technical assistance in the laboratory.

\section{REFERENCES:}

1. Chang, H.Y., Y. L. Ho, M. J. Sheu, Y. H. Lin, M. C. Tseng, S. H. Wu, G. J. Huang, and Y. S. Chang.. Antioxidant and free radical scavenging activities of Phellinus merrillii extracts. Botany Studies. 2007, 48: 407-417.

2. Chang, S. T. and P. G. Miles.. Mushroom-Cultivation, Impact (2nd ed). CRC Press. London, 2004 27-37.

3. Friedman, M. Mushroom polysaccharides: Chemistry and anti-obesity, antidiabetes, anticancer, and antibiotic properties in cells, rodents, and humans. Foods. 2016. 5: 62-80.

4. Ofodile, L. N., N. U. Uma, T., Kokubum, O. R. J. Grayer, O.T Ogundipe, and M. S. J. Simmonds. Antimicrobial colossolactones from the Nigerian polypore Ganoderma colossum (Fr). Phytotherapia Research. 201126: 748751

5. Chang, S.T. and S.P. Wasser.. The role of culinarymedicinal mushrooms on human welfare with a pyramid model for human health. International Journal of Medicinal Mushrooms. 2012 14: 95-134.

6. Jeong., H. J., S. J. Yoon, and Y. R. Pyun.. Polysaccharides from edible mushroom $\mathrm{Hi}$ nmogi (Tremella fuciformis) inhibit differentiation of 3T3-L1 adipocytes by reducing mRNA expression of PPAR $\gamma, C / E B P \alpha$, and leptin. Food Science and Biotechnology. 2008, 17:267-273.

7. Kanagasabapathy, G., S. N. A. Malek, A. A. Mahmood, K. H. Chua, S. Vikineswary, and U. R. Kuppusamy.. Betaglucan-rich extract from Pleurotus sajor-caju (Fr.) Singer prevents obesity and oxidative stress in C57BL/6J Mice fed on a high-fat diet. Evidence-Based Complementary \& Alternative Medicine. Special Issue 2013, 185-259.

8. Nyam, K. L., C. F. Chow, C. S. Tan, and S.T. Ng.. Antidiabetic Properties of the Tiger's milk medicinal mushroom, Lignosus rhinocerotis (Agaricomycetes), in streptozotocin-induced diabetic rats. International Journal of Medicinal Mushrooms. 2017, 19: 607-617.

9. Wang, K., L. Bao, W. Xiong, K. Ma, J. Han, W. Wang, W. Yin, and $\mathrm{H}$. Liu. Lanostane triterpenes from the tibetan medicinal mushroom Ganoderma leucocontextum and their inhibitory effects on HMG-CoA reductase and $\alpha$ - 
glucosidase. Journal of Nature Production. 2015. 78: 1977-1989.

10. Wojcicki, J.M. and M.B. Heyman. Reducing childhood obesity by eliminating $100 \%$ fruit juice. American Journal Public Health. . 2012, 102(9):1630-1633.

11. Piskov, S., L., Timchenko, W-D., Grimm, I., Rzhepakovsky, S., Avanesyan, M., Sizonenko, , V. K. Kurchenko Effects of Various Drying Methods on Some Physico-Chemical Properties and the Antioxidant Profile and ACE Inhibition Activity of Oyster Mushrooms (Pleurotus ostreatus) Foods 2020, 9:160; doi:10.3390/foods9020160

12. Hassan, F., \& G. M. Medany. Effect of pretreatments and drying Temperatures on the quality of dried Pleurotus mushroom SPP. Egypt. Journal of Agriculture Research, 2014, 92:1009-1023.

13. Moreau, R. A. Extraction and Analysis of Food Lipids. Chapter 5 in Methods of Analysis of Food Components and Additives. Chemical and Functional Properties of Food Components series. Semih Otles, editor. Published by CRC Press, Taylor and Francis Group, Boca Raton, FL. USA. 2005.

14. AOAC Official Methods of Analysis -17th ed. Association of Official Analytical Chemist, Maryland. 2002.

15. Khan, A., M. R. Mohammad, T. Mousumi, F. S. Nusrat, Ah. $\mathrm{Xu}$, and C. Han-chun. Antioxidative potential of Duranta repens (linn.) Fruits against h2o2 induced cell death in vitro, Afr J Traditional Complementary and Alternative Medicine, 2013.10(3): 436-441.

16. Hartree, E.F. Determination of protein - Modification of Lowry method that gives a linear photometric response. Analytical Biochemistry. 1972. 48:422-427.

17. Ashraf, S., H. Zaneb, M.S. Yousaf, A. Ijaz, M.U. Sohail, S.Muti, M.M. Usman, S. ljaz, and H. Rehman. Effect of dietary supplementation of prebiotics and probiotics on intestinal microarchitecture in broilers reared under cyclic heatstress. Journal of Animal Physiology and Animal Nutrition. 2013. 97: 68-73.

18. Skoog, D. A., F. J. Holler, and S.R. Crouch, Principles of instrumental analysis. 6th ed. Brooks Cole; Belmont, CA, USA. 2006.

19. Celen, S., K. Kahveci, U. Akyol, and A. Haksever. Drying behaviour of cultured mushrooms. Journal of Food Processing and Preservation. 2010. 34(1):27-42. Https://Doi.Org/10.1111/J.1745-4549.2008.00300

20. Bawatharani, R.. Effect of size of mushrooms on drying rate in a natural convection solar dryer. International Journal of Research Publication. 2018, 9(I): 1-8 http://ijrp.org/paper_detail/309

21. Kulshreshtha, M., A. Singh, and D.A. Vipu.. Effect of Drying Conditions on Mushroom Quality. Journal of
Engineering Science and Technology. 2009, 4(1): 90 98.22. Ogawa, T. and S. Adachi. Measurement of moisture profiles in pasta during rehydration based on image process. Food and Bioprocess technology. 2014. 7(5):1465-1471.

23. Mallikarjuna, S. E., A. Ranjini, D. J. Haware, M. R. Vijayalakshmi, M. N. Shashirekha, and S. P. P. Rajarathnam,. Mineral Composition of Four Edible Mushrooms, Journal of Chemistry. 2013, 1-5. https://doi.org/10.1155/2013/805284.

24. Bano, Z., K., Nagaraja, S. Vibhakar, and O. P. Kapur, "Minerals and heavy metal contents in the sporophores of Pleurotus species," Mushroom Newsletter Tropics 1981, .2: 3-7.

25. Williams, J. W. Obstetrics: A Text-book for the Use of Students and Practitioners, Appleton 1904 Harvard University18 Jun 2008, 845pp

26. Mbuge, D. O. and E. B. K. Mutailnfluence of heat treatment on Vitamin C Levels in Oyster Mushroom Invention. Journal of Research Technology in Engineering \& Management. . 2018. 8: 47-52.

27. Yuen, S. K., Kalianon, and M. A. Atong, Effect of Different Drying Temperatures on the Nutritional Quality of Edible Wild Mushroom, Volvariella Volvacea Obtained Nearby forest Areas. International Journal of Advanced Research. 2014. 2 (5): 859-864

28. Indian Council of Medical Research. Nutrient Requirements and Recommended Dietary Allowances for Indians, A Report of the Expert Group of the Indian Council of Medical Research, National Institute of Nutrition, Hyderabad, 1990

29. Falandysz J. K., Szymczyk, H. Ichihashi, L. Bielawski, M. Gucia, A Frankowska, S-I Yamasaki.. "ICP/MS and ICP/AES elemental analysis (38 elements) of edible wild mushrooms growing in Poland." Food Additives and Contaminants. 2001 (18)6:503-513.

30. Bakken, L. R. and R. A. Olsen. Accumulation of radiocaesium in fungi." Canadian Journal of Microbiology. 1990, 36(10)704-710

31. Tüzen, M.. Determination of heavy metals in soil, mushroom and plant samples by atomic absorption spectrometry," Microchemical Journal. 2003, 74(3): 289-297,

32. Işlolu, M., F. Ylmaz, and M. Merdivan.. Concentrations of trace elements in wild edible mushrooms." Food Chemistry. 2001, 73(2) 169-175.

33. Durali, M. D., U. Ozgur, T. Musatafa, H. Erdogan, and S. Hayati, Trace metal levels in mushroom samples from Ordu, Turkey. Food Chemistry. 2005, 91 (3): 463-467. 